\title{
The Growth Comparison of Haematococcus pluvialis in Two Different Medium
}

\author{
Dina Soes Putri' ${ }^{1}$, Siti Alaa ${ }^{2}$ \\ ${ }^{1}$ Universitas Muhammadiyah Mataram, Mataram, West Nusa Tenggara, Indonesia \\ ${ }^{2}$ Universitas Mataram, Mataram, West Nusa Tenggara, Indonesia \\ Corresponding author: dina.soes.putri@gmail.com
}

\begin{abstract}
Microalgae is an aquatic microorganism that conducts photosynthesis. It plays a vital role as an oxygen producer in the marine ecosystem. A freshwater microalgae, Haematococcus pluvialis, has been utilized as a health supplement and industrial application which is beneficial for human. In addition to physical and chemical factors, nutrient composition is one crucial thing that contributes to the growth of microalgae. This present study aimed to determine and compare the growth rate of Haematococcus pluvialis cultivated in two culture medium, Walne's and Guillard. The culture conditions observed were light intensity, photoperiod of light-dark hours, temperature, inoculum concentration of medium's liquid, and cell density. This study confirmed that Walne's media produced much higher biomass $\left(247 \times 10^{4}\right.$ cells $\left./ \mathrm{mL}\right)$ than Guillard's medium $\left(209.6 \times 10^{4}\right.$ cells $\left./ \mathrm{mL}\right)$. The aspect to be further performed on $H$. pluvialis biomass is exploring its high-value bio compound.
\end{abstract}

Keywords: Guillard's medium, Haematococcus pluvialis; Microalgae growth, Walne’s medium.

\section{Introduction}

Microalgae, commonly known as plankton, is a photosynthetic organism living in a watery environment. Microalgae are playing an essential role as an oxygen producer in the aquatic ecosystem as well as the lowest food chain in the water (Promdaen, et al., 2014; Putri, D.S. et al., 2019). Microalgae, based on its environment can be classified as marine microalgae (living in saline water) and freshwater microalgae (Mobin and Alam, 2017). The well-known marine microalgae are Chlorella sp., Porpyridium sp., Dunaliella, Navicula, Amphora, Nitzchia, and Tetraselmis (Matsunaga et al., 2005). Meanwhile, the well-known freshwater microalgae are Arthrospira platensis (Spirulina), Chlamydomonas, and Haematococcus pluvialis (Masojídek and Torzillo, 2008).

Microalgae can be classified in many ways (Correa et al., 2017). The simplest way to distinguish them is by the color of its colony cells. The colorfulness of microalgae cells is provided by the dominance of photosynthetic pigment in its cell. Based on the color of the cells, microalgae can be classified into seven classes, those are green algae (dominantly by chlorophyll pigment), red algae (dominantly by astaxanthin pigment), brown algae (dominantly by fucoxanthin pigment), diatom, blue-green algae, coccolithophorids, and dinoflagellates (Alam, 2019; Chapman, 2013). As for Haematococcus, it belongs to green algae due to its green color of the cells. 
Microalgae-based research is increasing over the decades because of its high potency for commercial industries. Where some of its or the whole part can be used for many purposes, including: for agriculture as feed and biofertilizer, food industry as human food, antioxidant, and colorant (Bhalamurugan et al., 2018), pharmaceutical products such as dietary/food supplements to prevent many diseases and drugs/medicines (Bhalamurugan et al., 2018; Khan et al., 2018; Mimouni et al., 2015; Santhosh et al., 2016), cosmetics as moisturizing agent, thickener agent, antioxidant, UV protection, anti-aging, colorant in lipsticks and eye shadow (Bhalamurugan et al., 2018; Mourelle et al., 2017), renewable energy as biodiesel (Duong et al., 2012; Khan et al., 2018), biofuel, biohydrogen, solar cells (Lim et al., 2015; Putri, D. S. et al., 2015), and is also used in wastewater treatment (Wang et al., 2016). Indonesia as a tropical country and have a great area of water is very potential to develop research in microalgae.

Haematococcus pluvialis is a unicellular biflagellate green microalga that is notably known for its astaxanthin pigment. Astaxanthin derivate from Haematococcus pluvialis has been tested to several subjects and proven to have improved antioxidant, eye function, skin, immune system, male fertility, and also can inhibit cancer (Shah et al., 2016). Thus, this alga is very prospected to explore for commercial purposes. The highest production of astaxanthin pigments in Haematococcus pluvialis is when the alga growth in extreme conditions (red stage), such as lack of nutrients. While in a normal growth environment (green stage), the alga will produce more biomass (Butler et al., 2018).

To date, the research for Haematococcus pluvialis mostly focusing on optimization of astaxanthin production (Hernández et al., 2015; Li et al., 2019; Shah et al., 2016; Shao et al., 2019), but research in producing more biomass is rarely to find. Whereas biomass from microalgae can also beneficial for many applications, for example, it can be used as biofuel resources. Biomass production is determined by six factors: nutrition, salinity (for marine microalgae), temperature, light, $\mathrm{pH}$, and $\mathrm{CO}_{2}$ supply (Gatamaneni et al., 2018). Nutrition composition is playing an important role that affects the metabolite production, such as lipids, protein, carbohydrates, and pigments. The three most essential elements that must include in medium nutrition are carbon, nitrogen, and phosphor. Two kinds of medium nutrition that commonly used in culturing microalgae are Walne's and Guillard's medium. This research aimed to compare the growth rate of Haematococcus pluvialis in two different mediums, Walne and Guillard, and to find out the best medium for growing the alga (Juneja et al., 2013).

\section{Material and Method}

\subsection{Walne's Medium}

The composition of Walne's medium consist of three solutions, those are solution A, B, and C. Solution A (nutrient) was made of $20 \mathrm{~g}$ of $\mathrm{NaH}_{2} \mathrm{PO}_{4} .2 \mathrm{H}_{2} \mathrm{O}, 100 \mathrm{~g}$ of $\mathrm{NaNO}_{3}, 45 \mathrm{~g}$ of $\mathrm{Na}_{2}$ EDTA (anhydrous), $0.36 \mathrm{~g}$ of $\mathrm{MnCl}_{2} .4 \mathrm{H}_{2} \mathrm{O}, 1.3 \mathrm{~g}$ of $\mathrm{FeCl}_{3} .6 \mathrm{H}_{2} \mathrm{O}, 33.6 \mathrm{~g}$ of $\mathrm{H}_{3} \mathrm{BO}_{3}, 1 \mathrm{~mL}$ pf B solution, and made up to $1 \mathrm{~L}$ with aquadest. Solution B (trace metal) 
was made of $21 \mathrm{~g}$ of $\mathrm{ZnCl}_{2}, 20 \mathrm{~g}$ of $\mathrm{CoCl}_{2} \cdot 6 \mathrm{H}_{2} \mathrm{O}, 9 \mathrm{~g}$ of $\left(\mathrm{NH}_{4}\right)_{8} . \mathrm{Mo}_{7} \mathrm{O}_{24} 4 \mathrm{H}_{2} \mathrm{O}, 20 \mathrm{~g}$ of $\mathrm{CuSO}_{4} .5 \mathrm{H}_{2} \mathrm{O}$, a few drops of $\mathrm{HCl}$, and made up to $1 \mathrm{~L}$ with aquadest. While solution $\mathrm{C}$ (vitamin) was made of vitamin $\mathrm{B}_{12}$ (cyanocobalamin), vitamin $\mathrm{B}_{1}$ (thiamine- $\mathrm{HCl}$ ), and made up to $1 \mathrm{~L}$ with aquadest. Solution A then sterilized with steam pressure, while solution $\mathrm{C}$ sterilized with sterile filter membrane.

\subsection{Guillard's Medium}

The composition of Guillard medium also consists of three solutions, those are solution A, B, and C. Solution A (nutrient) was made of each $1 \mathrm{~mL}$ of $\mathrm{NaH}_{2} \mathrm{PO}_{4} .2 \mathrm{H}_{2} \mathrm{O}$ (5 $\mathrm{g} / \mathrm{L}), \mathrm{NaNO}_{3}(75 \mathrm{~g} / \mathrm{L}), \mathrm{Na}_{2} \mathrm{SiO}_{3} .9 \mathrm{H}_{2} \mathrm{O}(30 \mathrm{~g} / \mathrm{L})$, solution $\mathrm{B}$, and made up to $1 \mathrm{~L}$ with aquadest. Solution B (trace metal) was made of $3.15 \mathrm{~g}$ of $\mathrm{ZnCl}_{2} .7 \mathrm{H}_{2} \mathrm{O}(22 \mathrm{~g} / \mathrm{L}), 1 \mathrm{~mL}$ of $\mathrm{CoCl}_{2} .6 \mathrm{H}_{2} \mathrm{O}(10 \mathrm{~g} / \mathrm{L}), 4.36 \mathrm{~g}$ of $\mathrm{Na}_{2} \mathrm{EDTA}_{2} 2 \mathrm{H}_{2} \mathrm{O}, 1 \mathrm{~mL}$ of $\mathrm{MnCl}_{2} .4 \mathrm{H}_{2} \mathrm{O}(180 \mathrm{~g} / \mathrm{L}), 3.15 \mathrm{~g}$ of $\mathrm{FeCl}_{3} .6 \mathrm{H}_{2} \mathrm{O}, 1 \mathrm{~mL}$ of $\mathrm{CuSO}_{4} .5 \mathrm{H}_{2} \mathrm{O}(9.8 \mathrm{~g} / \mathrm{L}), 1 \mathrm{~mL}$ of $\mathrm{Na}_{2} \mathrm{MoO}_{4} .2 \mathrm{H}_{2} \mathrm{O}(6.3 \mathrm{~g} / \mathrm{L})$, and made up to $1 \mathrm{~L}$ with aquadest. While solution $\mathrm{C}$ (vitamin) was made of $1 \mathrm{~mL}$ of vitamin $\mathrm{B}_{12}$ (1 $\mathrm{g} / \mathrm{L}$ ), $200 \mathrm{~g}$ of vitamin $\mathrm{B}_{1}$ (thiamine- $\mathrm{HCl}$ ), $1 \mathrm{~mL}$ of vitamin $\mathrm{H}$ (biotin), and made up to $1 \mathrm{~L}$ with aquadest. Solution A then sterilized with steam pressure, while solution $\mathrm{C}$ sterilized with sterile filter membrane.

\subsection{Culture of Microalgae}

Microalgae were cultured in a sterile environment using the Batch technique. Culture total volume was $900 \mathrm{ml}$, algal inoculum was $90 \mathrm{ml}(10 \%$ of total culture volume), nutrient solution added was $900 \mu \mathrm{l}(0,1 \% \mathrm{v} / \mathrm{v})$, and vitamin solution added was $90 \mu \mathrm{l}(0,01 \% \mathrm{v} / \mathrm{v})$. The culture conditions were: 24 hours of light photoperiod, the light intensity of 2000 lux, room temperature of $28{ }^{\circ} \mathrm{C}$, and aeration for 24 hours. One mL of culture sample was observed daily under a microscope to counted the biomass production (cell density) using hemocytometer Neubauer.

\section{Results and Discussion}

Haematococcus pluvialis was cultured under conditions shown in Table 1, and then the cell density is shown in Table 2.

Table 1. Culture Conditions

\begin{tabular}{ll}
\hline \multicolumn{2}{c}{ Culture Conditions } \\
\hline Light intensity & $2000-2500$ lux \\
Photoperiod (light: dark) & 24 hours light: 0 hour dark \\
Temperature & $26-28{ }^{\circ} \mathrm{C}$ \\
Aeration & 24 hours \\
\hline
\end{tabular}

Table 2. Cells Density Calculation

\begin{tabular}{lccccccc}
\hline \multicolumn{7}{c}{ Cells density $\left(\times \mathbf{1 0}^{\mathbf{4}}\right.$ cells $\left./ \mathbf{m L}\right)$} \\
\hline Day(s) & $\mathbf{0}$ & $\mathbf{1}$ & $\mathbf{2}$ & $\mathbf{3}$ & $\mathbf{4}$ & $\mathbf{5}$ & $\mathbf{6}$ \\
Walne & 9.28 & 19.81 & 32.43 & 78.20 & 170.96 & 220.2 & 247.0 \\
Guillard & 9.28 & 20.17 & 40.35 & 72.93 & 156.2 & 188.2 & 209.6 \\
\hline
\end{tabular}


In which, the parameter of light (intensity and photoperiod) and temperature were in optimum condition (Lavens \& Sorgeloos, 1996; Masojídek \& Torzillo, 2008), then the alga was growth in a green stage (Butler et al., 2018). The appearance of culture color is shown in Figure 1. Initially, the culture liquid was transparent due to relatively low cell density. The initial cell density was $9.28 \times 10^{4}$ cells $/ \mathrm{mL}$. After day 1 , the culture began to show the greenish color, which means the algae is growing well in both mediums and became greener day by day and ever darker since day 5 . From the culture liquid, it can be seen the difference in cell density, where the Walne's culture was greener than Guillard culture since day 4, which means algae biomass production in Walne's is higher and is supported by the daily cell density counting in Table 2.
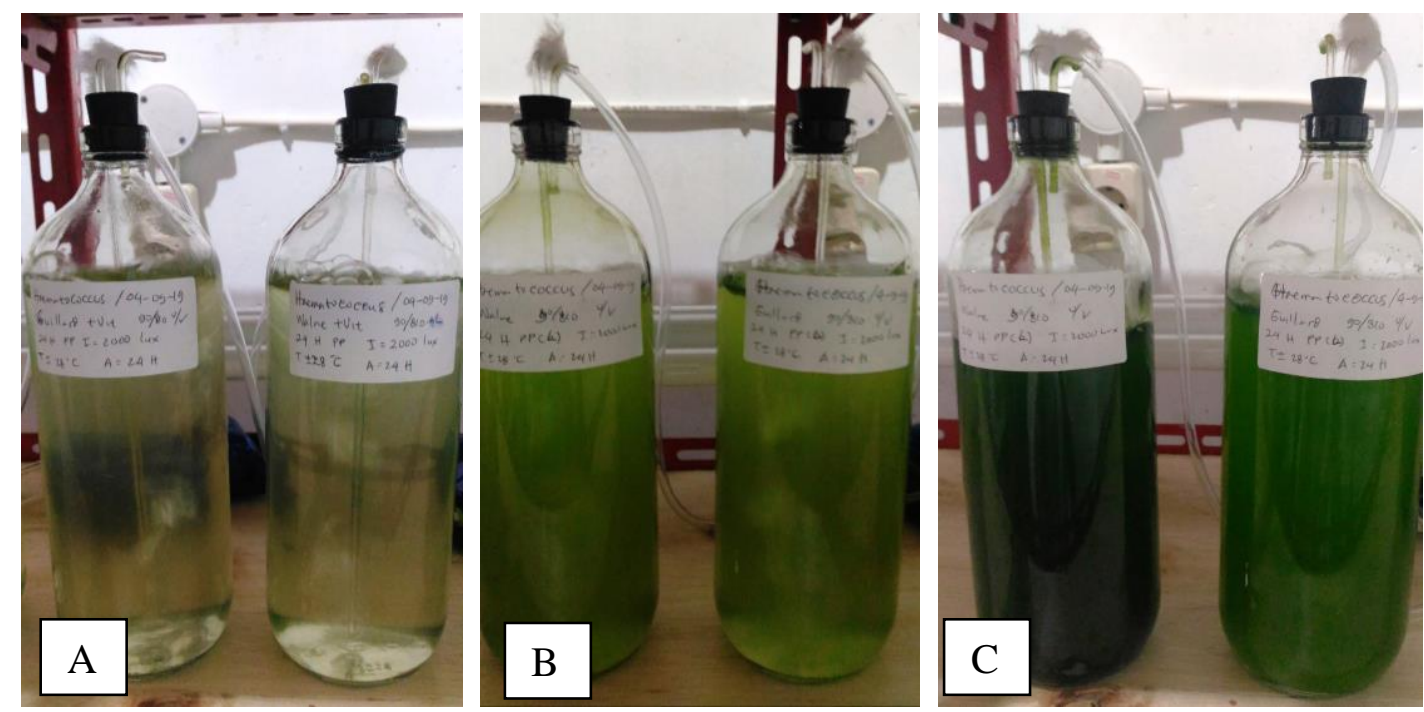

Figure 1. Culture of Haemotococcus pluvialis in Walne's medium (left) and Guillard's medium (right): $d-0$ (A); d-2 (B); d-6 (C)

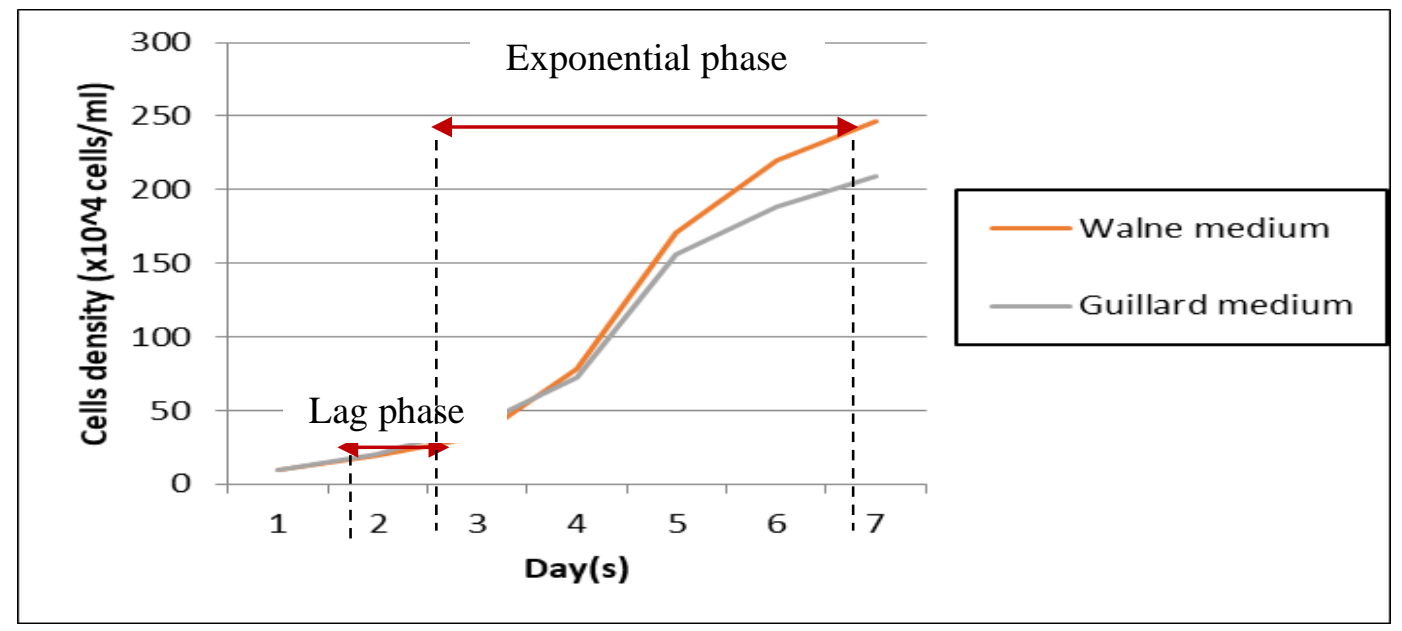

Figure 2. The growth curve of Haematococcus pluvalis in two different medium 
Based on Table 2, it can be seen that initially, the cell density of Guillard's medium is leading at days 1 and 2 . It can be explained because the inoculum was cultured in Guillard's medium previously. So, the alga is already adapted in this medium. Meanwhile, for Walne's culture, the cell density is lower because it enters the lag/induction phase at days 1 and 2 (see the growth curve of Haematococcus pluvialis in Figure 2). The lag phase is indicated by a little increase in algal cell density due to adaptation in a new environment (Fatemeh and Mohsen, 2016).

The second stage, the exponential phase, is seen to begin since day 3. At this phase, algae start to proliferate to the peak (Perumal et al., 2015). On day 3, the cell density of both mediums is relatively almost the same. But since day four the cell density in Walne's medium is higher than in Guillard's and the differences in cell density (biomass production) were getting wider over days (Figure 2). After six days of culture, the color of the culture remains darker (Figure 1) and also indicates that the alga is still growing. It means that the alga lifespan is more than a week, in other report show that Haematococcus pluvialis peak in growing is on day 13 and began to enter the death phase since day 15 (Muzaki, et al., 2008).

There were only two stages detected on the growth curve of Haematococcus pluvialis in this research due to uncontinuous cell counting after day 6, while the overall growth stages of algae averagely including five stages: lag phase, exponential phase, phase of declining relative growth, stationary phase, and the death phase. Based on the data and the growth curve, it can be concluded that biomass production of Haematococcus pluvialis is higher in Walne's medium than in Guillard's. It means that nutrition in Walne's medium is better than Guillard for the growth of Haematococcus pluvialis, even though the composition of those mediums is relatively similar.

The difference between Walne's and Guillard's medium is the existence of sodium silicate and vitamin $\mathrm{H}$ in Guillard and the proportion of Nitrogen (N) and Phosphor (P) elements content in both mediums. Where in Walne, the $\mathrm{N}$ and $\mathrm{P}$ compounds are higher ( $20 \mathrm{~g}$ and $100 \mathrm{~g}$ per L volume) than in Guillard ( $1 \mathrm{~mL}$ each per L volume). Nitrogen is needed for the formation of protein (the building blocks of the cell) and nucleic acid, while phosphor (in the form of phosphate) is part of the backbone of DNA and RNA, which are genetic materials that essential for the human life (Juneja et al., 2013). Furthermore, research showed that the increase of nitrate $\left.\mathrm{NO}_{3}\right)$ utilization would increase the protein content by up to $44.3 \%$ (Panahi et al., 2019). That is why the biomass production in Walne's is higher than in Guillard's medium due to the wide difference in $\mathrm{N}$ and $\mathrm{P}$ concentration. So, for further culturing of Haematococcus pluvialis, Walne's medium is recommended than the Guillard.

\section{Conclusion}

This research presented information that Walne's medium was able to supply better nutrition for Haematococcus growth than the Guillard's. Due to the medium's content which nitrate (contained nitrogen element) and phosphate (including phosphor 
element) content are higher in Walne's. Thus, for producing more biomass of Haemotococcus pluvialis culture, using the Walne's medium is recommended.

\section{Acknowledgment}

We gratefully acknowledge the support of the Ministry of Research, Technology, and Higher Education of Indonesia for the grant.

\section{References}

Alam, T. (2019). Extraction of Natural Colors from Marine Algae. Journal of Agricultural and Marine sciences [JAMS], 23 (1), 81-91. http://doi.org/10.24200/jams.\% 20vol23iss0pp81-91

Bhalamurugan, G. L., Valerie, O., \& Mark, L. (2018). Valuable bioproducts obtained from microalgal biomass and their commercial applications: A review. Environmental Engineering Research, 23(3), 229-241. https://doi.org/10.4491/eer.2017.220

Butler, T. O., McDougall, G. J., Campbell, R., Stanley, M. S., \& Day, J. G. (2018). Media screening for obtaining Haematococcus pluvialis red motile macrozooids rich in astaxanthin and fatty acids. Biology. https://doi.org/10.3390/biology7010002

Chapman, R. L. (2013). Algae: The world's most important "plants"-an introduction. Mitigation and Adaptation Strategies for Global Change. https://doi.org/10.1007/s11027-010-9255-9

Correa, I., Drews, P., Botelho, S., De Souza, M. S., \& Tavano, V. M. (2017). Deep learning for microalgae classification. Proceedings - 16th IEEE International Conference on Machine Learning and Applications, ICMLA 2017, 2017-Decem(December), 20-25. https://doi.org/10.1109/ICMLA.2017.0-183

Duong, V. T., Li, Y., Nowak, E., \& Schenk, P. M. (2012). Microalgae isolation and selection for prospective biodiesel production. Energies. https://doi.org/10.3390/ en5061835

Fatemeh, L., \& Mohsen, D. (2016). Effects of Environmental Factors on the Growth, Optical Density and Biomass of the Green Algae Chlorella Vulgaris in Outdoor Conditions. Journal of Applied Sciences and Environmental Management. https://doi.org/10.4314/jasem.v20i1.16

Gatamaneni, B. L., Orsat, V., \& Lefsrud, M. (2018). Factors Affecting Growth of Various Microalgal Species. Environmental Engineering Science. https://doi.org/10.1089/ees.2017.0521

Hernández Morales, K. J., Pérez Morales, M. E., Jáuregui Romo, C., Alcántara Jurado, L. A., \& Hurtado Ayala, L. A. (2015). Production conditions of astaxanthin by Haematococcus pluvialis: Literature review 2003-2013. Revista Mexicana de Ciencias Farmaceuticas. 
Juneja, A., Ceballos, R. M., \& Murthy, G. S. (2013). Effects of environmental factors and nutrient availability on the biochemical composition of algae for biofuels production: A review. Energies. https://doi.org/10.3390/en6094607

Khan, M. I., Shin, J. H., \& Kim, J. D. (2018). The promising future of microalgae: Current status, challenges, and optimization of a sustainable and renewable industry for biofuels, feed, and other products. Microbial Cell Factories. https://doi.org/10.1186/s12934-018-0879-x

Lavens, P., \& Sorgeloos, P. (1996). Manual on the production and use of live food for aquaculture. In Fao Fisheries Technical Paper. https://doi.org/10.1017/CB09781107415324.004

Li, F., Cai, M., Lin, M., Huang, X., Wang, J., Zheng, X., ... An, Y. (2019). Accumulation of Astaxanthin Was Improved by the Nonmotile Cells of Haematococcus pluvialis. BioMed Research International. https://doi.org/10.1155/2019/8101762

Lim, A., Haji Manaf, N., Tennakoon, K., Chandrakanthi, R. L. N., Lim, L. B. L., Bandara, J. M. R. S., \& Ekanayake, P. (2015). Higher performance of DSSC with dyes from cladophora sp. As mixed cosensitizer through synergistic effect. Journal of Biophysics. https://doi.org/10.1155/2015/510467

Masojídek, J., \& Torzillo, G. (2008). Mass Cultivation of Freshwater Microalgae. In Encyclopedia of Ecology, Five-Volume Set. https://doi.org/10.1016/B978008045405-4.00830-2

Matsunaga, T., Takeyama, H., Miyashita, H., \& Yokouchi, H. (2005). Marine microalgae. Advances in Biochemical Engineering/Biotechnology. https://doi.org/10.1007/b135784

Mimouni, V., Ulmann, L., Haimeur, A., Guéno, F., Meskini, N., \& Tremblin, G. (2015). Marine microalgae used as food supplements and their implication in preventing cardiovascular diseases. OCL - Oilseeds and Fats, Crops and Lipids. https://doi.org/10.1051/ocl/2015015

Mobin, S., \& Alam, F. (2017). Some Promising Microalgal Species for Commercial Applications: A review. Energy Procedia. https://doi.org/10.1016/j.egypro.2017.03.177

Mourelle, M. L., Gómez, C. P., \& Legido, J. L. (2017). The potential use of marine microalgae and cyanobacteria in cosmetics and thalassotherapy. Cosmetics. https://doi.org/10.3390/cosmetics4040046

Muzaki, A., Fahrudin, F., Wardana, I. K., \& Haryanti, H. (2008). Kultur Mikroalga Haematococcus pluvialis Untuk Menghasilkan Astaxantin. Jurnal Riset Akuakultur. https://doi.org/10.15578/JRA.3.3.2008.351-361 
Panahi, Y., Khosroshahi, A. Y., Sahebkar, A., \& Heidari, H. R. (2019). Impact of cultivation condition and media content on Chlorella vulgaris composition. Advanced Pharmaceutical Bulletin. https://doi.org/10.15171/apb.2019.022

Perumal, S., Thirunavukkarasu, A. R., \& Pachiappan, P. (2015). Advances in Marine and Brackishwater Aquaculture. In S. Perumal, T. A.R., \& P. Pachiappan (Eds.), Advances in Marine and Brackishwater Aquaculture. https://doi.org/10.1007/978-81-3222271-2

Promdaen, S., Wattuya, P., \& Sanevas, N. (2014). Automated Microalgae Image Classification. Procedia Computer Science, 29, 1981-1992. https://doi.org/10.1016/j.procs.2014.05.182

Putri, D.S., Astuti, S. P., \& Alaa, S. (2019). The growth of microalgae Chlorococcum sp. isolated from Ampenan estuary of Lombok Island in Walne's medium. AIP Conference Proceedings, 2199. https://doi.org/10.1063/1.5141301

Putri, Dina Soes, Nurachman, Z., \& Nurbaiti, S. (2015). Pigmen fotosintesis dari mikroalga laut porpyridium cruentum sebagai pemeka sel surya. Jurnal Agrotek UMMat, 2(2), 11-18.

Santhosh, S., Dhandapani, R., \& Hemalatha, N. (2016). Bioactive compounds from Microalgae and its different applications-a review. Pelagia Research Library Advances in Applied Science Research.

Shah, M. M. R., Liang, Y., Cheng, J. J., \& Daroch, M. (2016). Astaxanthin-producing green microalga Haematococcus pluvialis: From single cell to high value commercial products. Frontiers in Plant Science. https://doi.org/10.3389/fpls.2016.00531

Shao, Y., Gu, W., Jiang, L., \& Zhu, Y. (2019). Study on the Visualization of Pigment in Haematococcus pluvialis by Raman Spectroscopy Technique. Scientific Reports. https://doi.org/10.1038/s41598-019-47208-2

Wang, Y., Ho, S.-H., Cheng, C.-L., Guo, W.-Q., Nagarajan, D., Ren, N.-Q., ... Chang, J.-S. (2016). Perspectives on the feasibility of using microalgae for industrial wastewater treatment. Bioresource Technology, 222, 485-497. https://doi.org/10.1016/j.biortech.2016.09.106 